\title{
Hubungan Konformitas Peer Group Dengan Perilaku Berpacaran Pada Remaja
}

\author{
Dwinda Gusty Anindani ${ }^{1)}$, Uswatun Hasanah ${ }^{2, b)}$, Cholilawati ${ }^{3)}$ \\ b)us nina@yahoo.com \\ ${ }^{1,2)}$ Program Studi Pendidikan Kesejahteraan Keluarga \\ ${ }^{3)}$ Program Studi Tata Busana \\ Fakultas Teknik, Universitas Negeri Jakata \\ J In. Rawamangun Muka, J akarta Timur. 13220
}

\begin{abstract}
Abstrak
Penelitian ini bertujuan untuk menganalisis hubungan antara konformitas peer group dengan perilaku berpacaran remaja. Metode penelitian yang digunakan adalah metode survey dengan pendekatan korelasional, dengan teknik pengambilan sampel menggunakan multistage sampling yang terdiri dari simple random sampling dan purposive sampling. Sampel penelitian ini adalah 233 siswa di SMP Negeri 209 Jakarta. Hasil penelitian diketahui bahwa: korelasi antara konformitas peer group dengan perilaku berpacaran remaja sebesar 0,467; konformitas peer group berkontribusi terhadap perilaku berpacaran sebesar $21,83 \%$; dan terdapat hubungan yang positif dan signifikan antara konformitas peer group dengan perilaku berpacaran pada remaja di SMP Negeri 209 Jakarta.
\end{abstract}

Kata kunci: konformitas peer group, perilaku berpacaran, remaja.

\section{Correlation Between Peer-Group Conformity with Adolescent Dating Behavior}

\begin{abstract}
This study is aimed at analyzing the relation between peer group conformity and teenagers dating behavior. This study uses a survey method with correlational approach, while multistage sampling (simple random sampling and purposive sampling). The sample was 233 students in SMP Negeri 209 Jakarta.The research found that: coefficient correlation between peer group conformity with adolescent dating behaviors of 0,467 ; conformity peer group contributing to the dating behavior of $21.83 \%$; and there is a positive and significant relationship between peer group conformity with dating behavior in adolescents in SMP Negeri 209 J akarta.
\end{abstract}

Keywords: peer-group conformity, dating behavior, adolescent. 


\section{PENDAHULUAN}

Era globalisasi memungkinkan masuknya budaya asing. Akibat banyaknya kebudayaan asing yang masuk. Beberapa dari kebudayaan asing tersebut tidak cocok dengan kebudayaan Indonesia, contohnya yang terjadi pada remaja seperti bullying, perilaku merokok, tawuran, dan perilaku pacaran. Perilaku tersebut bisa menimbulkan ketidakseimbangan mental pada remaja ketika terjadi perubahan secara fisik dan psikologis dari masa kanak-kanak ke masa dewasa. Sering dijumpai remaja dapat bergaul dengan lawan jenis (pacaran) di tempat-tempat umum dengan bebas tanpa memperdulikan masyarakat sekitarnya.

Remaja saat ini sudah mengenal istilah pacaran sejak awal masa remaja. Pacar, bagi mereka merupakan salah satu bentuk gengsi yang membanggakan dan bisa mengakibatkan terjadinya persaingan untuk mendapatkan pacar atau status sosial. Dari permasalahan di atas remaja harus diselamatkan dari globalisasi yang memiliki nilai negatif. Generasi muda yang merupakan tulang punggung bangsa, yang diharapkan di masa depan mampu meneruskan tongkat estafet kepemimpinan bangsa ini agar lebih baik. Persiapan generasi muda menjadi generasi penerus sangat tergantung kepada kesiapan masyarakat yakni dengan keberadaan budayanya. Kehidupan masyarakat yang penuh dengan nilai-nilai kehidupan Timur yang didominasi oleh ajaran-ajaran agama dan budaya. Seperti diketahui bahwa kebutuhan biologis (seksualitas) sifatnya seperti kebutuhan makan, akan tetapi pemahaman seksualitas tidak lepas dari konteks sosial budaya yang telah ikut mengaturnya Pemahaman perilaku dan orientasi seksualitas dapat berbeda dari satu budaya ke budaya lain atau dari jangka waktu satu ke jangka waktu yang lain.

Perubahan sosial mulai terlihat dalam persepsi masyarakat yang pada mulanya meyakini seks sebagai sesuatu yang sakral menjadi sesuatu yang tidak sakral lagi. Hal itu dapat dilihat dari perilaku pacaran yang dewasa ini mulai melampaui batas norma dengan melakukan aktifitas seksual tanpa ikatan pernikahan.

Aktivitas seks pra-nikah di kalangan remaja dan pelajar dari tahun ke tahun tidak pernah menurun, bahkan sebaliknya terus mengalami peningkatan. Penelitian yang dilakukan BKKBN tahun 2008 menghasilkan data bahwa 63\% remaja di beberapa kota besar di Indonesia telah melakukan seks sebelum nikah (BKKBN.com diakses tanggal 3 Januari 2015). Sedangkan penelitian yang dilakukan di 4 kota besar (Medan, DKI Jakarta, Bandung dan Surabaya) oleh Departemen Kesehatan tahun 2009 menyebutkan bahwa 6,9 \% pelajar SMA pernah melakukan hubungan seks pranikah (nad.bkkbn.go.id diakses tanggal 14 Januari 2015). Pada tahun 2010 mengalami peningkatan $51 \%$ remaja di jabodetabek melakukan hubungan seks pranikah (kompas.com diakses tanggal 1 Januari 2015). Tahun 2011 survey yang dilakukan Komisi Perlindungan Anak Indonesia (KPAl) mengalami peningkatan kembali sebanyak $62,7 \%$ remaja SMP tidak perawan, 21,2\% remaja mengaku pernah aborsi (arrahmah.com diakses tanggal 2 Januari 2015). Tahun 2012 kembali meningkat menjadi 93,7\% pernah melakukan hubungan intim (sindo.com diakses tanggal 2 Januari 2015).

Menurut data yang disampaikan Komisi Perlindungan Anak Indonesia (KPAl) kepada koran Tempo pada tanggal 2 November 2013 yang dikutip pada 27 Oktober 2014, ada beberapa kasus pornografi dan pornoaksi hingga oktober 2013 ini. Seluruhnya dilakukan oleh anak-anak dari kalangan pelajar di bawah umur, khususnya di Jakarta. Jumlah tersebut terdiri dari pergaulan seks bebas dan kepemilikan media pornografi, tak sedikit pula yang hamil di luar nikah. Rentang usia yang melakukan seks pranikah berkisar antara 13-18 tahun.

Jumlah remaja yang mengalami masalah perilaku seks pranikah terus bertambah akibat pola hidup seks bebas. Pada kenyataannya pengaruh gaya seks bebas yang mereka terima 
jauh lebih kuat dari kontrol yang mereka terima daripada pembinaan secara keagamaan baik dari orang tua maupun mendapatkannya sendiri. Hal ini menjadi bukti ancaman perilaku seks pranikah di kalangan remaja, khususnya di DKI Jakarta dan sekitarnya semakin merajalela. Faktor- faktor yang menyebabkan terjadinya perilaku seks pranikah menurut Hyde (1990) yaitu: usia, usia yang muda saat berhubungan seksual pertama, usia saat menstruasi pertama, agama, pacar, kencan yang lebih awal, pengalaman pacaran/kencan (hubungan afeksi), orang tua, teman sebaya (peers group).

Dalam perkembangan kehidupan sosial remaja juga ditandai dengan gejala meningkatnya pengaruh teman sebaya dalam kehidupan mereka. Sebagian besar waktunya dihabiskan untuk berhubungan atau bergaul dengan teman-teman sebaya mereka (Santrock,1998 dalam Desmita 2009: 219). Hubungan teman sebaya remaja lebih didasarkan pada hubungan persahabatan.

Kelompok sebaya menyediakan suatu lingkungan, yaitu tempat teman sebayanya dapat melakukan sosialisasi dengan nilai yang berlaku, bukan lagi nilai yang ditetapkan oleh orang dewasa, melainkan oleh teman seusianya, dan tempat untuk menentukan jati dirinya. Namun, apabila nilai yang dikembangkan dalam kelompok sebaya adalah nilai negatif maka akan menimbulkan bahaya bagi perkembangan jiwa individu begitu pun sebaliknya.

Kuatnya pengaruh kelompok temansebaya juga mengakibatkan melemahnya ikatan individu dengan orang tua, sekolah, dan norma-norma konvensional. Selain itu, banyak waktu yang diluangkan individu di luar rumah bersama teman-teman sebayanya daripada dengan orang tuanya. Remaja mengartikan bahwa teman sebaya adalah tempat untuk belajar bebas dari orang dewasa, belajar menyesuaikan diri dengan kelompok, belajar berbagi rasa, bersikap sportif, belajar menerima dan melaksanakan tanggung jawab. Teman sebaya memegang peranan penting selama masa remaja, dorongan untuk memiliki kesamaan dalam nilai, kebiasaan, dan trend menjadi begitu kuat sehingga remaja melakukan konformitas terhadap kelompok sebayanya (peer group). Dimana tingkah laku konformitas itu sendiri meningkat pada masa remaja awal.

Konformitas adalah suatu perubahan tingkah laku atau keyakinan sebagai hasil nyata dari tekanan yang diberikan oleh kelompok dan juga bertingkah laku dalam hal berusaha memenuhi harapan dari kelompok dengan sedikit ataupun tanpa tekanan untuk melakukan tingkah laku tertentu. Konformitas juga dapat dipengaruhi oleh lingkungan pendidikan seperti pertemanan dengan teman sebaya di sekolah atau dengan pengajar.

Berdasarkan hasil studi pendahuluan, SMP Negeri 209 Jakarta merupakan salah satu SMP di Jakarta timur, memiliki passing grade ke-656 dalam data yang dimiliki oleh Dinas Pendidikan dan kebudayaan DKI Jakarta. Setiap tahunnya mengalami peningkatan nilai akademiknya, meningkatnya nilai akademik yang baik juga diharapkan dengan meningkatnya karakter yang baik dan tidak disikapi dengan menurunnya karakter diri tiap siswa-nya. Dari 15 orang siswa, yang diwawancarai ditemukan fakta adanya beberapa gejala kerusakan karakter atau perilaku yang terjadi karena konformitas peer group yang berkaitan dengan penyimpangan perilaku berpacaran remaja, banyak siswa yang sudah kehilangan kontrol dalam peer group dengan cara berpacaran dengan teman sebayanya hingga membuat pembicaraan yang terarah menuju penyimpangan perilaku dalam berpacaran.

Remaja lebih banyak berada di luar rumah bersama peer group atau kelompok sebaya. Seperti yang kita ketahui di dalam peer group, remaja berusaha menemukan konsep dirinya, tetapi sangat berbahaya apabila kelompok sebaya ini cenderung tertutup, dimana setiap anggota tidak dapat terlepas dari kelompoknya dan harus mengikuti pimpinan kelompok, mulai dari sikap, pemikiran dan gaya hidup.

Remaja cenderung untuk membuat standar seksual sesuai dengan standar teman sebaya secara umum, remaja cenderung untuk menjadi lebih aktif secara seksual apabila memiliki 
kelompok teman sebaya yang demikian, serta apabila mereka mempercayai bahwa teman sebayanya aktif secara seksual di samping kenyataan itu bahwa teman sebayanya sebenarnya memang aktif atau tidak secara seksual pengaruh kelompok teman sebaya pada aktivitas seksual remaja terjadi melalui dua cara yang berbeda, namun saling mendukung. Pertama, ketika kelompok teman sebaya aktif secara seksual, mereka menciptakan suatu standar normatif bahwa hubungan seks bebas adalah suatu yang dapat diterima. Kedua, teman sebaya menyebabkan perilaku seksual satu sama lainnya secara langsung, baik melalui komunikasi diantara teman ataupun dengan pasangan seksualnya.

Berdasarkan pembahasan di atas, dapat kita ketahui bahwa teman sebaya atau peer group ternyata memiliki pengaruh terhadap kehidupan remaja tak terkecuali dalam hal seksualitas remaja seperti informasi, nasihat, contoh, serta dorongan kepada remaja untuk melakukan hubungan seksual.

Hal ini sesuai dengan penelitian yang dilakukan oleh Richard dan Kenneth (2010) yang menghasilkan fakta bahwa norma kelompok teman sebaya memberikan pengaruh yang besar pada waktu dimulainya seks. Berdasarkan fenomena yang terjadi di atas, penulis tertarik untuk mengetahui bagaimana hubungan konformitas peer group dengan perilaku dalam berpacaran pada remaja Konformitas Peer Group

Terdapat banyak sekali pengertian mengenai konformitas yang dikemukakan oleh para ahli. Kiesler \& Kiesler (1969) dalam myers, 1996:223) menyatakan bahwa:

"Conformity is a change in behavior or belief as a result of real or imagined group pressure"

Pernyataan di atas menunjukan bahwa konformitas merupakan perubahan perilaku atau kepercayaan diakibatkan oleh tekanan kelompoknya. Jadi, ketika remaja mendapatkan tekanan untuk melakukan suatu hal, maka akan mempengaruhi perubahan perilaku remaja itu sendiri. Sementara tokoh lain, (Morgan et al., 1986:166): "Confirmity is the situation in which individuals change their beliefs or behaviors so that they become similar to those of other group member"

Perilaku remaja biasanya akan mengikuti standar kebiasaan pada suatu kelompok. Seseorang merubah perilakunya dengan tujuan agar diterima oleh kelompoknya. Pada penjelasan lain, Baron (2008) berpendapat bahwa konformitas adalah sebuah fenomena sosial di mana seseorang menyesuaikan tingkah laku, sikap, dan pandangan agar sesuai dengan orang lain atau kelompok. Jadi, di dalam konformitas terdapat suatu tekanan yang tidak terlihat oleh individu yang memaksa seseorang bertingkah laku sesuai dengan apa yang di harapkan kelompok.

Dari uraian di atas dapat disimpulkan bahwa konformitas itu sendiri adalah suatu perubahan tingkah laku atau keyakinan sebagai hasil nyata dari tekanan yang diberikan oleh kelompok dan juga bertingkah laku dalam hal berusaha memenuhi harapan dari kelompok dengan sedikit ataupun tanpa tekanan untuk melakukan tingkah laku tersebut. Dalam konformitas ini ada tekanan dari kelompok dimana individu dapat merasakan baik secara nyata ataupun tidak nyata, atau dalam imajinasinya. Oleh karena itu, konformitas bukan hanya berarti bertingkah laku seperti orang lain tetapi berpengaruh oleh cara kelompok itu bertindak, dan tindakan ini akan berbeda jika dilakukan sendirian. Individu juga ditempatkan pada suatu konflik antara nilai dan pendapatnya dengan nilai dan norma-norma yang dianut oleh kelompok.

Selain itu menurut Sears (1991:81-86) mengemukakan secara eksplisit bahwa konformitas remaja ditandai dengan hal sebagai berikut:

\section{Kekompakan}

Kekuatan yang dimiliki kelompok acuan menyebabkan seseorang tertarik dan ingin tetap 
menjadi anggota kelompok. Eratnya hubungan seseorang dengan kelompok acuan disebabkan perasaan suka antara anggota kelompok serta harapan memperoleh manfaat dari keanggotaannya. Harapan akan kekompakan kelompok dapat muncul dalam dua perilaku, yaitu:

a. Penyesuaian diri

Kekompakan yang tinggi menimbulkan tingkat konformitas yang semakin tinggi.

b. Perhatian terhadap kelompok

Peningkatan konformitas terjadi karena anggotanya enggan disebut sebagai orang yang menyimpang. Seperti yang telah kita ketahui, penyimpangan menimbulkan resiko ditolak.

2. Kesepakatan

Pendapat kelompok acuan yang sudah dibuat memiliki tekanan kuat sehingga seseorang harus loyal dan menyesuaikan pendapatnya dengan pendapat kelompok. Kesepakatan dalam kelompok dimunculkan dalam beberapa hal, yaitu:

a. Kepercayaan

Penurunan melakukan konformitas yang drastic karena hancurnya kesepakatan disebabkan oleh faktor kepercayaan. Tingkat kepercayaan terhadap mayoritas akan menurun bila terjadi perbedaan pendapat, meskipun orang yang berbeda pendapat itu sebenarnya kurang ahli jika dibandingkan dengan anggota lain yang membentuk mayoritas.

b. Persamaan pendapat

Jika dalam suatu kelompok terdapat satu orang saja yang tidak sepakat dengan anggota kelompok yang lain maka konformitas akan turun. Kehadiran orang yang tidak sependapat tersebut menunjukan terjadinya perbedaan yang dapat berakibat pada berkurangnya kesepakatan kelompok. Jadi dengan persamaan pendapat antara anggota kelompok maka konformitas akan semakin tinggi.

3. Ketaatan

Tekanan atau tuntutan kelompok acuan pada seseorang membuatnya rela melakukan tindakan walaupun remaja tidak menginginkannya. Bila ketaatannya tinggi maka konformitasnya akan tinggi juga. Tekanan karena ganjaran, ancaman, atau hukuman adalah salah satu cara untuk menimbulkan ketaatan. Dengan meningkatkan tekanan terhadap individu untuk menampilkan perilaku yang diinginkan melalui ganjaran, ancaman, atau hukuman karena akan menimbulkan ketaatan yang semakin besar.

\section{Perilaku Berpacaran}

Perilaku berpacaran memiliki definisi dan faktor di antaranya, perilaku berpacaran menurut sarwono (2007:142) adalah segala tingkah laku yang didorong oleh hasrat seksual, baik dengan lawan jenisnya maupun dengan sesama jenis.

Perilaku seseorang dalam berpacaran sangat beragam. Menurut Umsoriah (2008) perilaku berpacaran antara lain:

1. Perilaku berpacaran dalam bentuk ekspresi fisik seperti berpegangan tangan, mencium kening, berciuman bibir, mencium leher, saling meraba (payudara dan kelamin), dan melakukan hubungan seks (Sugiyati,2008).

2. Perilaku berpacaran dalam bentuk pernyataan verbal. Perilaku dalam bentuk verbal bertujuan untuk memastikan dan mendapat pengakuan dari orang yang dicintainya berani dan percaya diri mengungkapkan rasa cinta baik melalui telepon, member suatu benda yang berupa lambing cinta seperti coklat, boneka, dan lainnya atau mengungkapkan rasa cinta di hadapan pacar dan teman- temannya.

3. Perilaku berpacaran dalam bentuk pengungkapan diri. Pasangan remaja saling mengungkapkan hatinya kepada pacar dalam bentuk pengungkapan perasaan agar 
perasaan yang terpendam atau permasalahan yang dipendam dapat dibantu untuk dicarikan solusinya.

4. Perilaku berpacaran dengan memberi materi atau hadiah. Memberikan hadiah sebagai bentuk perhatian, memberikan hadiah di saat ulang tahun, nmendapatkan prestasi atau setelah bertengkar sebagai penebusan rasa dosa dan permohonan maaf.

Berdasarkan pengertian di atas dapat disimpulkan bahwa perilaku berpacaran adalah segala tingkah laku yang didorong oleh hasrat seksual, baik dengan lawan jenisnya maupun dengan sesama jenis yang tidak sejalan dengan norma dalam masyarakat.

\section{Aspek-Aspek dalam Perilaku Berpacaran}

Menurut Dianawati (2003) seorang remaja melakukan perilaku berpacaran ini terbagi dalam beberapa faktor, yaitu sebagai berikut:

a. Tekanan yang Datang dari TemanPergaulannya

Lingkungan pergaulan yang telah dimasuki oleh seorang remaja dapat juga berpengaruh untuk menekan temannya yang belum melakukan hubungan seks.

b. Adanya Tekanan dari Pasangannya

Karena kebutuhan seseorang untuk mencintai dan dicintai, seseorang harus rela melakukan apa saja terhadap pasangannya, tanpa memikirkan resiko yang nanti dihadapinya.

c. Adanya Kebutuhan Badaniah

Seks menurut beberapa ahli merupakan kebutuhan dasar yang tidak dapat dipisahkan dari kehidupan seseorang. Jadi, wajar saja jika semua orang, tidak terkecuali remaja menginginkan hubungan seks ini, sekalipun akibat dari perbuatannya tersebut tidak sepadan dibandingkan dengan risiko yang akan mereka hadapi

d. Rasa Penasaran

Ada usia remaja, rasa keingintahuannya begitu besar terhadap seks. Apalagi jika temantemannya mengatakan bahwa seks terasa nikmat, ditambah lagi adanya masalah seks.

\section{METODE PENELITIAN}

Penelitian ini dilakukan pada 233 sampel dari kelas VII dan VIII di SMP Negeri 209 Jakarta. Teknik Pengambilan sampel menggunakan metode Survey dengan teknik pengumpulan data jenis Multistage sampling Instrumen penelitian adalah kuesioner dengan variabel Konformitas Peer Group (Sears, 1991) dan variabel Perilaku Berpacaran (Dianawati, 2003). Instrumen variabel $X$ menggunakan item dengan skala Likert sedangkan instrument Variabel $Y$ menggunakan skala Guttman.Skala Konformitas Peer group dengan memodifikasi instrumen yang disusun oleh Sears (1991) dan terdiri dari 31 item pertanyaan.Dengan dimensi kekompakan, kesepakatan dan ketaatan.Skala Perilaku Berpacaran dengan memodifikasi instrumen yang disusun oleh Dianawati (2003) dan terdiri dari 23 item pertanyaan.Dengan dimensi tekanan dari teman sebaya, tekanan dari pasangan, kebutuhan badaniah, rasa penasaran,pelampiasan diri,lingkungan keluarga

\section{HASIL DAN PEMBAHASAN}

Berdasarkan penelitian yang telah dilakukan, diketahui nilai koefisien korelasi rxy sebesar 0,467 dan $t_{\text {hitung }}$ sebesar $8,031>t_{\text {tabel }}$ sebesar 1,97 sehingga dapat disimpulkan bahwa terdapat hubungan positif antara Konformitas Peer Group dengan Perilaku Berpacaran remaja. Nilai ini memberikan pengertian bahwa ada hubungan positif antara Konformitas Peer Group dengan 
Perilaku Berpacaran Remaja, semakin tinggi konformitas Peer Group maka semakin tinggi segala informasi yang tidak terbatas masuknya. maka, rasa penasaran tersebut semakin mendorong mereka untk lebih jauh lagi melakukan berbagai macam percobaan sesuai yang diharapkannya

\section{Pelampiasan Diri}

Faktor ini tidak hanya datang dari diri sendiri. Misalnya, karena terlanjur berbuat, seorang remaja perempuan biasanya berpendapat bahwa sudah tidak ada lagi yang dapat dibanggakan dalam dirinya.

\section{Lingkungan Keluarga}

Bagi seorang remaja, mungkin aturan yang diterapkan oleh kedua orangtuanya tidak dibuat berdasarkan kepentingan kedua belah pihak (orangtua dan anak). Akibatnya, remaja tersebut merasa tertekan, sehingga ingin membebaskan diri dengan menunjukkan sikap sebagai pemberontak, yang salah satunya dalam Perilaku Berpacaran pada remaja. Demikian pula sebaiknya semakin rendah Konformitas Peer Group, semakin rendah pula Perilaku Berpacaran pada remaja.

Variabel Konfomitas Peer Group yang diukur dari dimensi kekompakan, kesepakatan dan ketaatan serta variabel Perilaku Berpacaran yang diukur dari dimensi adanya tekanan dari teman sebaya, adanya tekanan dari pasangan, adanya kebutuhan badaniah, pelampiasan diri, rasa penasaran, dan lingkungan keluarga. Dari hasil perhitungan terdapat hubungan yang kuat antara kedua variabel. Dilihat dari hubungan antara Dimensi Kekompakan pada variabel Konformitas peer group dengan dimensi Tekanan dari teman sebaya, dimensi kekompakan dengan dimensi adanya tekanan dari pasangan, dimensi kekompakan dengan dimensi adanya kebutuhan badaniah, dimensi kekompakan dengan dimensi pelampiasan diri, dan dimensi kekompakan dengan lingkungan keluarga pada variable perilaku berpacaran memiliki tingkatan hubungan yang rendah.

Ternyata dengan adanya penyesuaian diri dan perhatian kelompok tidak terlalu berhubungan dengan remaja yang mendapatkan tekanan dan rasa ingin berhubungan seksual yang diterima dari temannya, tidak terlalu berhubungan dengan remaja yang membiarkan dirinya dikontrol oleh orang lain dan motif-motif ingin tahu tentang seksualitas yang diterima dari temannya, serta tidak berpengaruh dengan remaja yang menunjukan kemampuannya untuk menampilkan perasaan yang dirasakan untuk hubungan seksual di SMP Negeri 209 Jakarta.

Kemudian dilihat hubungan antara dimesi kekompakan pada variable konformitas peer group dengan dimensi rasa penasaran pada variabel perilaku berpacaran memiliki hubungan yang sedang. Artinya dengan adanya penyesuaian diri dan perhatian terhadap kelompok ketika berada diluar rumah berhubungan sedang dengan ketaatan remaja terhadap kelompok sebayanya dan peraturan yang berlaku. Remaja bertingkah laku sesuai dengan aturan yang ada di dalam kelompok sebayanya di SMP Negeri 209 Jakarata.

Selanjutnya dilihat dari dimensi kesepakatan pada variabel konformitas peer group dengan dimensi Tekanan dari teman sebaya, dimensi kesepakatan dengan dimensi adanya tekanan dari pasangan, dimensi kesepakatan dengan dimensi adanya kebutuhan badaniah, dimensi kesepakatan dengan dimensi pelampiasan diri, dan dimensi kesepakatan dengan lingkungan keluarga pada variabel perilaku berpacaran memiliki tingkatan hubungan yang rendah. Artinya dengan adanya Kepercayaan dan persamaan pendapat di dalam kelompok yang ditimbulkan hanya berhubungan rendah dengan remaja yang memiliki pengakuan untuk meniru apa yang dilakukan teman-teman dengan pacarnya, melakukan aktifitas sesuai dengan teman- temannya di SMP Negeri 209 Jakarta.

Kemudian dilihat dari Dimensi Kesepakatan pada variabel konformitas peer group dengan 
dimensi rasa penasaran pada variabel Perilaku berpacaran memiliki tingkatan hubungan yang sedang. Artinya dengan adanya kepercayaan dan persamaan pendapat berhubugan rendah dengan membuat timbulnya rasa untuk menimbulkan ingin berhubungan seksual dengan pacar karena dorongan dari teman- temannya di SMP Negeri 209 Jakarta.

Sedangkan untuk dimensi ketaatan pada variabel konformitas peer group dengan dimensi Tekanan dari teman sebaya, dimensi ketaatan dengan dimensi adanya tekanan dari pasangan, dimensi ketaatan dengan dimensi adanya kebutuhan badaniah, dimensi ketaatan dengan dimensi pelampiasan diri, dimensi ketaatan dengan rasa penasaran dan dimensi ketaatan dengan lingkungan keluarga pada variabel perilaku berpacaran memiliki tingkatan hubungan yang rendah. Artinya ketaatan mempunyai hubungan yang rendah membuat adanya kebutuhan rasa mencintai dan dicintai dari pasangan untuk berinteraksi dengan teman sebayanya dan membuat terjadinya keterlibatan seksual secara ilmiah.

Ketaatan juga mempunyai hubungan yang rendah dengan membuat adanya kebutuhan badaniah dalam bentuk control atau hubungan seksual dalam kelompok sebayanya. Ketika dalam ketaatan juga mempunyai hubungan yang rendah rasa penasaran maka remaja akan menyangkut penemuan dasar dan pengalaman seksualitas dari rasa ingin tahu yang mengikuti dari ketaatan dalam kelompok teman sebayanya. Bila ketaatan juga mempunyai hubungan yang rendah memiliki keinginan untuk pelampiasan diri maka remaja akan rela melakukan apa saja tanpa berfikir rasional hingga tidak akan menolak untuk melakukan hubungan seksual. Selain itu ketaatan mempunyai hubungan yang rendah juga berkaitan dengan pengaruh yang ada pada lingkungan keluarga yang dirasakan untuk melakukan secara mendalam dan menampilkan perasaan subjektif pada seseorang.

\section{KESIMPULAN}

Berdasarkan pengolahan deskriptif, analisis, dan pengolahan data statistik maka dapat disimpulkan bahwa:

1. Ada hubungan yang signifikan antara Konformitas Peer Group dengan Perilaku Berpacaran pada remaja kelas VII dan VIII di SMP Negeri 209 Jakarta. Koefisien Korelasi positif, artinya hubungan bersifat positif dimana semakin tinggi Konformitas Peer Group yang dimiliki maka akan semakin tinggi Perilaku Berpacaran remaja kelas VII dan VIII SMP Negeri 209 Jakarta.

2. Hasil perhitungan uji analisis statistik menyatakan bahwa 21,83 persen variabel Konformitas Peer Group berkontribusi dengan Perilaku Berpacaran, sedangkan sisanya berhubungan dengan faktor lain.

3. Dimensi Kekompakan pada variable konformitas peer group dengan dimensi rasa penasaran pada variabel Perilaku berpacaran memiliki tingkatan hubungan yang sedang.

4. Dimensi Kekompakan dengan dimensi Tekanan dari teman sebaya, dimensi kekompakan dengan dimensi adanya tekanan dari pasangan, dimensi kekompakan dengan dimensi adanya kebutuhan badaniah, dimensi kekompakan dengan dimensi pelampiasan diri, dan dimensi kekompakan dengan lingkungan keluarga memiliki tingkatan hubungan yang rendah.

5. Lalu untuk dimensi kesepakatan dengan dimensi Tekanan dari teman sebaya, dimensi kesepakatan dengan dimensi adanya tekanan dari pasangan, dimensi kesepakatan dengan dimensi adanya kebutuhan badaniah, dimensi kesepakatan dengan dimensi pelampiasan diri, dan dimensi kesepakatan dengan lingkungan keluarga memiliki tingkatan hubungan yang rendah.

6. Kemudian Dimensi Kesepakatan pada variable konformitas peer group dengan dimensi rasa penasaran pada variabel Perilaku berpacaran memiliki tingkatan hubungan yang sedang. 
7. Sedangkan untuk dimensi ketaatan dengan dimensi Tekanan dari teman sebaya, dimensi ketaatan dengan dimensi adanya tekanan dari pasangan, dimensi ketaatan dengan dimensi adanya kebutuhan badaniah, dimensi ketaatan dengan dimensi pelampiasan diri, dimensi memiliki tingkatan hubungan yang rendah.

\section{DAFTAR PUSTAKA}

2002. Psikologi Perkembangan: Suatu Pendek atan Sepanjang Rentang Kehidupan.

Surabaya: Erlangga

2010. Prosedur P enelitian: S uatu Pendek atan Praktik. Jakarta: Rineka Cipta.

2007. Promosi Kesehatan dan IImu Perilak u-perilak u. Jakarta: Rineka Cipta.

2005. Skala Penguk uran Variabel-Variabel Penelitian. Bandung: Alfabeta.

2000. P sik ologi Remaja. Jakarta: PT. Raja Grafindo Persada.

2003. P sik ologi Remaja. Jakarta: PT. Raja Grafindo Persada.

2006. P sik ologi Remaja. Jakarta: PT. Raja Grafindo Persada.

2007. Psik ologi Remaja. Jakarta: Yayasan Bina Pustaka.

Ali, Moh dan Asrori, M. 2009. Psikologi Remaja Perkembangan Peserta Didik. Jakarta: Penerbit Bumi Aksara.

Agustiani, Hendriati. 2009. Psikologi Perkembangan (Pendekatan Ekologi Kaitannya dengan Konsep Diri dan Penyesuaian Diri pada Remaja). Bandung: PT Refika Aditama.

Baron, R. A dkk. 2008. Social Psychology. New York: Pearson Education.

Desmita. 2006. Psik ologi Perkembangan, Cetak an ke-2. Bandung: Remaja Rosdakarya.

Dianawati, Ajen. 2006. Pendidikan Seks Untuk Remaja. Jakarta: Kawan Pustaka.

Djaali dan Muljono. 2008. Penguk uran Dalam Bidang Pendidik an. Jakarta: PT. Grasindo.

Gunarsa. 1981. Psik ologi Remaja. Jakarta: BPK Gunung Agung.

Hurlock, Elizabeth B. 2004. Psikologi Perkembangan: Suatu Pendek atan Sepanjang Rentang

Kehidupan (Terjemahan Instiwidayanti dan S oedjarwo). Edisi Kelima. Jakarta: Erlangga.

Hayde, J.S. 1990. Understanding Human S exuality. $4^{\text {th }}$ Ed Saint Louis: McGraww- Hill, Inc.

Kartini, Kartono. 1986. Patologi Sosial. Jakarta: Rajawali.

Kartini, Kartono. 1986. Patologi S osial. Jakarta: Rajawali.

Mappiare, Andy. 1982. Psikologi Remaja. Surabaya: Usaha Nasional.

Maryati, Kun dan Suryawati, Juju. S osiologi. Jakarta: Penerbit Erlangga.

Notoatmodjo S. 2003. Pendidikan dan Perilaku Kesehatan. Jakarta: Rineka Cipta.

Noor, Juliansyah. 2013. Metodologi penellitian. Jakarta: Prenada Media Group.

Puspitawati, H. dan Herawati, T. 2013. Metode Penelitian Keluarga. Bogor: IPB Press.

Riduwan. 2004. Metode dan Teknik Menyusun Tesis. Bandung: Alfabeta.

Branscombe. 2008. Social Psychology. Pearson International Edition. USA: Pearson.

Suryoputro, dkk. 2006. Fak tor-fak tor yang mempengaruhi Perilaku Seksual Remaja Di J awa

Tengah: Implik asinya Terhadap Kebijakan Dan Layanan Kesehatan Sek sual dan Reproduk

si. Makara Kesehatan.

Sugiyono. 2006. Statistika Untuk Penelitian. Cetakan Ketujuh. Bandung: CV. Alfabeta.

Santoso, Santosa. 1999. Dinamik a Kelompok Sosial. Jakarta: Bumi Aksara.

Santrock, John. W. 2003. Adolescence Perkembangan Remaja Terjemahan

Sangadji, E. M. dan Sopiah. 2010. Metodologi Penelitian. Yogyakarta: Andi Offset.

Sears, dkk. 1991. Psik ologi Sosial. Alih bahasa Michael Adryanto dan Savitri Soekrisno. Edisi 5, Jilid 1. Jakarta: Erlangga.

Shelton, W. L. 2002. Monosex Tilapia Production Through Androgenesis.19 ${ }^{\text {th }}$ Annual Technic al 
Report. USA: Oregon State University, Corvallis.

Sugiono. 2005. Metode Penelitian Administrasi. Bandung: Alfabeta.

Sugiono. 2008. Metode Penelitian Kuantitatif, Kualitatif dan R\&D. Bandung: PT. Refika Aditama. 